\title{
IAMJ
}

INTERNATIONAL

AYURVEDIC

MEDICAL JOURNAL

\section{ELUCIDATING VYADHIJANAKTVA OF KUSHTA IN TERMS OF SHEETOSHNA VYATYASA NIDANA}

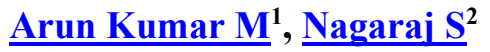

${ }^{1}$ Assistant professor and $\mathrm{PhD}$ Scholar,

${ }^{2} \mathrm{PhD}-$ Guide, Professor and HOD, Department of Roga Nidan,

Sri Dharmasthala Manjunatheshwara College of Ayurveda and Hospital, Kuthpady, Udupi, Karnataka, India

Corresponding Author: arunsdm@rediffmail.com

https://doi.org/10.46607/iamj1109032021

(Published online: March 2021)

Open Access

(C) International Ayurvedic Medical Journal, India 2021

Article Received: 07/02/2021 - Peer Reviewed: 11/02/2021 - Accepted for Publication: 17/02/2021

\section{(A) Check for updates}

\section{ABSTRACT}

The entity by which something is produced specifically is known as Nidana. It is Adikarana-means to prime factor among diverse determinants of disease. Illness is because of different causes and its effect is seen in the form of linga-symptoms of a disease. Because of which ancient seers propounded the Trisutra Ayurveda, namely hetu-linga and Aushadha. In many contexts of Samhitha, while Nidana engendering Vyadhi, Guna- properties are described, because properties have considerable importance in pharmacological, pathological action. One such context is Kushta Nidana, where aetiology delineated as Sheetoshna Vyatyasa - interchange use of cold and hot properties. This article foregrounded on the proposition of Karya-Karana-Vada of Ayurveda, to throw light on the expository of Gunas in manifesting Kushta.

Keywords: Sheeta Guna, Ushna Guna, Kushta

\section{INTRODUCTION}

Guna (property) is the second category of the Vaisheshika School of philosophy. Along with the
Dravya (drug or a substance) and Karma (action), Guna (property) forms the triad. This triad has an actual 
existence. Among the triad which has an actual existence, properties are very important since we consume substance for their properties. Jesus Christ stated that if the salt is not having its taste, it is good enough only to be put on the ground and tramped. Substances are sought by us for their properties. Ayurveda has surpassed all other philosophies in the enumeration of guna. This is mainly because Ayurveda is a practical science. In the practical application of substances for various uses, Ayurveda has to consider their properties because properties have considerable importance say in pharmacological, pathological action of substances. In Ayurveda, knowledge of a substance invariably invites the knowledge of its properties owing to its pathological aspects.

Aim and Objective: To critically analyse the Sheetha (cold) and Ushna Guna (hot quality). To elucidate Sheetha and Ushna Guna in manifestation of Kushta.

Methodology: A conceptual study is made after reviewing Ayurvedic texts and their commentaries, relevant data from articles, periodicals, journal and published articles, internet media.

Insight into the Guna: The term guna (property) is derived from the root guna(property)which means Amantrana, to invite, since properties invite people to substances, it is known by the name guna (property) ${ }^{1}$. According to Charaka Samhita, guna (property) is the inherent and inert cause. Charaka enumerates 41 properties classified into four groups, Namely arthaguna, gurvadigunah, paradiguna and aatmaguna. Among them, gurvadiguna's are 20 in number and many terms used to denote the 20 properties, few are vimshatiguna, shareeraguna, samaanyaguna and rasa bhoutikadrvayakarmagunah. Though the last name is lengthy, prefers to physico-chemical and pharmacological properties and it is descriptive of the true nature of the group. Amid vimshatiguna, sheeta (cold) and ushna guna (hot in property) need to go into detail, as these are mentioned as a prime cause in manifestation of kushta. Sheeta (cold) is opposite to ushna (hot). Cold substances are endothermic as they extract heat from the environment and reduce heat in the substances in contact with them. In vaisheshika and tarka philosophies, sheeta (cold) is the subdivision of sparsha (touch), sparsha (touch) being ushna (hot), sheeta (cold) and anushnasheeta (neither hot nor cold). Cold touch is the innate property of the primary existent water. In Ayurveda Sheeta (cold) is a Guna (quality) as well as a Veerya (potency). From a pharmacological point of view, cold substances are generally anabolic whereas hot substances are catabolic. Cold substances are Sthambhakas ${ }^{2}$ arrest movement and they cause stagnation. They are used for arresting flows of substances in the body. According to Sushruta Samhita, substances with cold properties generate pleasure hladana, are stagnating-sthambhana and are indicated in fainting- moorcha, thirst- trishna, burning sensationdaha and excessive sweating-sveda ${ }^{3}$. Bhava Prakasha expresses the same idea. Of these six Rasas (taste), Madhura (sweet), Tikta (bitter) and Kashaya (astringent) rasas (tastes) are Sheeta (cold) in Nature ${ }^{4}$. Amla Rasa (sour taste) is sheeta (cold) in sparsha (touch) but Ushna (hot) in veerya (potency). Madhura (sweet) vipaka (post digestive effect) is sheeta (cold) in nature. Sheeta guna (cold qualities) increases Kapha (One of the three basic humours of body) and Vata Dosha, (One of the three basic humours of body) and reduces pitta (One of the three basic humours of body). Philosophies consider Ushna (hot) as a type of sparsha (touch) and it is innate in the existent Agni (digestive fire) is opposite to Sheeta (cold)and is especially digestive. Ushna (hot)is also considered as veerya (potency) in Ayurveda. Ushna guna (hot in quality) produces diaphoresis, generate sweating. In Ayurvedic context, Ushna (hot) to sparsha (touch) and Ushnaveerya (hot in potency) are to be differentiated. Madhya (alcoholic preparations) may be cold to touch, but on consuming it, it produces sveda (perspiration). Hence it is hot in potency. Ushna (hot) is a very important pharmacological property in Ayurveda as in the final enumeration of potencies into two Ushna (hot)is the one and another being Sheeta(cold). Ushna (hot)causes Bhrama (giddiness), glaani (languor), trishna(thirst), daaha (burning) and Ashupakita (easy and quick digestion) ${ }^{5}$. It reduces Vata and Kapha (basic humours of body), it increases pitta (One of the three basic humours of body). We can group all the properties into two diametrically opposing batches, Ushna (hot)and sheeta (cold). 


\section{DISCUSSION}

In aetiology of all types of Kushtas, it is described as non-compliance of the prescribed rules concerning the order of resorting to Ushna (hot)and Sheeta (cold) regiments is the prime factor ${ }^{6}$. Chakrapani further stated that sheeta (cold) and Ushna (hot) regimens should be adopted in particular order ${ }^{7}$. Adoption of cold regimens immediately after hot regimens and vice versa, and also the adoption of cold and hot regimens in inappropriate time leads to the causation of Kustha. We can categorise most of dravya's(substance) mentioned in the Kushta Nidana into two batches of Sheeta-drvaya (cold substances) and UshnaDravya (hot substances). Not following Sheeta (cold) and Ushna (hot) food articles as per the Shastra is also a pattern of Sheetoshna Vyatyasa (exposure to sudden interchange use of cold and hot substance) and said to vitiate all three doshas (bodily humours). Though Sheetoshna Vyatyasa Nidanas (factors causing a sudden interchange of cold and hot substance), causes an increase of all three doshas (bodily humours/regulatory functional factors of body) in the body but do not expel them out of the body and they remain antagonistic to the Dhatus (tissue $)^{8}$. All drugs and diets which exhibit such action are to be regarded as unwholesome, viruddhaahara. Such regimens not only provoke the doshas (Bodily $\mathrm{Hu}$ mours regulatory functional factors of body) but also aggravate the dhatus (tissue).

Effect of Sheetoshnavyatyasanidana in Agni Dusti and Amotpatti:

For proper maintenance of positive health, food is the key factor. The agni (digestive fire), the power of digestion and metabolism, upon which depends the quantity of food intake, varies according to the season and the age of the individual ${ }^{9}$. Saatmyaahara (habituated food) taken in excess quantity for more duration or mutually contradictory substances may cause Agni dushti (vitiation of digestive fire) and it is believed to be Aama Pradoshaka (disorders due to undigested food) ${ }^{10}$. Further, it is stated in Astanga Samgraha, Sheetoshna Vyatyas (sudden interchange use of cold and hot substance) has Atiabhishyandhi (excess production of moisture in the tissue) property and acts like Amavisha, a clinical condition characterised by the manifestation of toxic symptoms resembles those of the poisoning. The result of such toxicity may exhibit immediately or may produce the latent cumulative effect of that Garavisha (artificial poisons) ${ }^{11}$. The presentation in both situations is the manifestation of diseases including Asta Mahagadas (8 group of diseases having incurability) or may up end up with life. So Kushta which is one among Mahagada (diseases having incurability) may manifest with acute presentation or may present chronic in relation to Sheetoshna Vyatyasanidana.

\section{Effect of Sheetoshnavyatyasanidana in Dhatudusti:}

By nature, sheetoshna vyatyasa may result in Gunavipraheena-veerya i.e. with weak potency. Such a state is like Dushi visha (cumulative toxicity). Dhatupradoshan (diseases affecting dhatus) is the effect brought about by Dushivisha (cumulative toxicity) ${ }^{12}$. Residing in Rasa Dhatu produces Rasa Dhatuja Vikaras. Sheeetoshnavyatyasa, because of their contradiction in their potency, they vitiate Rakta Dhatu (blood tissue) and bound to cause diseases relating to shonita (blood) ${ }^{13}$. Deliquescent-Abhishyandi is (produce more moisture in the tissue) the quality culpable of undermining the Mamsavahasrotas (channels transporting muscle tissues) ${ }^{14}$. The result of Sheetoshna Vyatyasa (sudden interchange use of cold and hot substance) is Mahabhishyandhi ${ }^{15}$ (produce more moisture in the tissue), which is certain to vitiate Mamsa Dhatu (muscle tissue), con sequencing in obstruction of the channels of circulation. Sheetoshna vyatyasa nidana (factors causing sudden interchange of cold and hot substance) may also result in Rasadi Dhatu Dusti (tissue disorder) with no Doshaprakopa (aggravation of bodily humours), by its Vishistashakti (special power) ${ }^{16}$, which cannot be even expelled out. The intricate corollary is the aberrant action of Dhatus and bringing forth Rasadi Dhatu Krita Vyadhi (tissue disorder) namely Kushtadi. The etymological meaning of Lasika (lymph) is flowing out with the same level and shining in character. Lasika (lymph) is the Udaka (water) and is found in between Mamsa (muscle) and Twak (skin) ${ }^{17}$. Lasika (lymph) is also considered as Rasamala (waste product of circulatory fluid). As Rasa (assimilated part of the food) and Mamsa Dhatu (muscle tissue) vitiated, in turn, vitiates lasika (lymph), which results in Shaithilya or looseness 
of dhatu. According to Charaka, the four Dhatus(tissue)are only generally affected and the specific vitiation of Dhatus (tissue) follows seriatim one after the other. In the primary stage of Kushta only four Dhatus (tissue) are vitiated, but subsequently, all other Dhatu's (tissue) in the entire body is affected. When all the Dhatus (tissue) are involved Oja Kshaya (decrease in essence of all dhatu) is certain ${ }^{18}$. The excellence of Dhatu is Saara (essence) ${ }^{19}$. Among the Asta-Saara (essence), Twak Saara (essence of skin) is affected in Kushta. The contributory factor for Twak Saara (essence of skin) is Sweda (sweat/perspiration). The fundamental action of Sweda is Kleda (body fluid) and Twak Soukumarya (delicate or soft skin) ${ }^{20}$. Sheetoshnaakramasevana is the explicit aetiology for Swedavaha Sroto Dusti (defect of sweat channel) ${ }^{21}$. Sweda Dusti, in turn, affects Twak Saara (essence of skin tissue). The absence of excellence of respective dhatu in the individual results in Saaraheenata (decrease in essence) which preferably results in Twak Shithilata.

Effect of Sheetoshnavyatyasanidana in Krimi Utpatti. Madhavakara remarks incompatible food combinations are one among the factors for genesis of Krimi(worm). Charaka mentions all the Kushta Nidanas are the reason for Raktaja Krimi Utpatti (worm originated from vitiated blood) ${ }^{22}$. Raktaja Krimis are six and these six causes only Kustha. As it is said in Sushruta, all the skin diseases are caused by the involvement of Vata, Pitta, Shleshma and Krimi (worm originated from vitiated 3 bodily humours \& blood $)^{23}$.

\section{Effect of Sheetoshnavyatyasanidana on Doshas.}

No kushta manifests itself because of the aggravation of only one dosha ${ }^{24}$. Sheetoshna Vyatyasanidana causes simultaneous vitiation of all three doshas (bodily humours). Sheetaguna (cold property substances) is said to aggravate Vata and kapha (bodily humours), whereas Ushna Guna (hot property substances) aggravates Pitta (bodily humour) and in combination, it is Tridosha Kopaka (aggravation of bodily humours). Considering the Margavorodha (obstruction of path) because of nidana (etiology), Dosha (bodily gains tiryakgati (oblique movement) ${ }^{25}$, affects Bahya Roga Marga (external path) ${ }^{26}$ and localised in Twagadi
Dhatus (body tissues), vitiates Dhatus (tissues) and so produce Kushta.

\section{CONCLUSION}

Nidana acts as Dosha Hetu or Vyadhi Hetu by their properties and action. Sometimes dosha vitiation by Sheeta guna, Ushna Guna or by Kramavyatyasa. At times Dosha Kopa by Katinya (gradual accumulation) or by Doshantara in terms of Anubandha or Samsarga, sometimes by several other mechanisms such as Ashayapakarsha etc. Nidana has a plurality in its causation of vitiation of any dosha. Elucidation of Nidana (etiology) is necessary for the proper identification of dosha (bodily humours), the Rogotpatti (disease origin), Rogavastha (disease stage), Roga Bala (strength of disease), and Sadhya-Asadhyata (prognosis) of disease. Understanding the different forms of $n i$ dana (etiology) gives us an important idea about the nature of disease manifestation. Sheetoshna Vyatyasa $\mathrm{Ni}$ dana has a pivotal role in vitiation of Agni (digestive fire), Dosha (bodily humours), Dhatudushti (tissues defect), and Krimiutpatti (infestation). Always the first line of treatment is Nidana Parivarjana- to avoid causative factor. So, focus to be laid on core principle of Sheetoshna Vyatyasa on Vyadhijanakatva (disease manifestation) - of Kushta and also in management of it.

\section{REFERENCES}

1. Agnivesha, Charaka, Dridabala, Charaka Samhita, Sutra Stana, Deerghanjivitiyaadhyaya, 1/51, edited by Yadavji Trikamji Acharya, Chaukhambha Sanskrit Sansthan, 2015; 13.

2. Hemadri, Hridaya, Sutra Sthaana, Aayushkameeya Adhyaya,1/18, edited byPandit Sadashiva Shastri, Chaukambha Surabharathi Prakashana, Varanasi,2017; 12.

3. Sushrutha, Sushrutha Samhita, Sutra Stana, Annapanavidhi Adhyaya,46/515, edited by Yadhavji Trikamaji Acharya, Chaukhambha Sanskrit Sansthan, Varanasi, $2017 ; 252$.

4. Vagbhata, Astanga Hridaya, Sutra Sthaana, Rasabhedeeya Adhyaya,10/10, edited by Pandit Sadashiva Shastri, Chaukambha Surabharathi Prakashana, Varanasi, $2017 ; 175$. 
5. Vagbhata, Astanga Hridaya, Sutra Sthaana, Dravyadivigyaneeyaadhyaya,9/18, edited by Pandit Sadashiva Shastri, Chaukambha Surabharathi Prakashana, Varanasi, 2017; 169.

6. Agnivesha, Charaka, Dridabala, Charaka Samhita, Nidana Stana, shoshanidanaadhyaya, 6/6, edited by Yadavji Trikamji Acharya, Chaukhambha Sanskrit Sansthan, 2015; 220.

7. Chakrapani, Charaka Samhita, Nidana Stana, shoshanidanaadhyaya, 6/6, edited by Yadavji Trikamji Acharya, Chaukhambha Sanskrit Sansthan, 2015; 220.

8. Agnivesha, Charaka, Dridabala, Charaka Samhita, Sutra Stana, Atreyabhadrakapyeya Adhyaya 26/85, edited by Yadavji Trikamji Acharya, Chaukhambha Sanskrit Sansthan, 2015; 150.

9. Chakrapani, Charaka Samhita, Sutra Stana, Matrashiteeya, 5/3, edited by YadavjiTrikamji Acharya, Chaukhambha Sanskrit Sansthan, 2015; 36.

10. Agnivesha, Charaka, Dridabala, Charaka Samhita, Vimana Stana, Trividhakuksheeya, 2/8, edited by Yadavji Trikamji Acharya, Chaukhambha Sanskrit Sansthan, 2015; 238.

11. Vagbhata, Astanga Hridaya, Sutra Sthaana, Aschotanaanjanavidhi Adhyaya, 23/29, edited by Pandit Sadashiva Shastri, Chaukambha Surabharathi Prakashana, Varanasi, 2017; 307.

12. Sushrutha, Sushruta Samhita, KalpaStana, AnnapanarakshakalpaAdhyaya,1/26-27, edited by Yadhavji Trikamaji Acharya, Chaukhambha Sanskrit Sansthan, Varanasi, 2017; 560.

13. Agnivesha, Charaka, Dridabala, Charaka Samhita, Sutra Stana, Atreyabhadrakapyeeya, 26/83, edited by Yadavji Trikamji Acharya, Chaukhambha Sanskrit Sansthan, $2015 ; 149$.

14. Sharangadhara, Sharangadhara Samhita, Pratama Kanda Kanda, Chaturtha Adhyaaya, 4/24, edited by Bramhananda Tripaati, Choukamba Surabharati Prakashana, 2010; 51.

15. Agnivesha, Charaka, Dridabala, Charaka Samhita, Sutra Stana, Atreyabhadrakapyeeya, 26/82, edited by Yadavji Trikamji Acharya, Chaukhambha Sanskrit Sansthan, $2015 ; 149$

16. Sushrutha, Sushruta Samhita, Chikithsa Stana, Hitahiteeya Adhyaya,20/3, edited by Yadhavji Trikamaji Acharya, Chaukhambha Sanskrit Sansthan, Varanasi, 2017; 94.

17. Chakrapani, Charaka Samhita, NidanaStana, Pramehanidana, $4 / 37$, edited by
18. Yadavji Trikamji Acharya, Chaukhambha Sanskrit Sansthan, 2015; 215

19. Chakrapani, Charaka Samhita, Nidana Stana, Gulmanidana, 3/4, edited by Yadavji Trikamji Acharya, Chaukhambha Sanskrit Sansthan, 2015; 208

20. Agnivesha, Charaka, Dridabala, Charaka Samhita, Vimana Stana, Rogabhishagjiteeya, 8/114, edited by Yadavji Trikamji Acharya, Chaukhambha Sanskrit Sansthan, 2015; 278

21. Sushrutha, Sushruta Samhita, ChikithsaStana, Doshadhatumalakshayavriddhivijnaneya,15/5, edited by Yadhavji Trikamaji Acharya, Chaukhambha Sanskrit Sansthan, Varanasi, 2017; 68.

22. Agnivesha, Charaka, Dridabala, Charaka Samhita, Vimana Stana, Srotasamvimana, 5/22, edited by Yadavji Trikamji Acharya, Chaukhambha Sanskrit Sansthan, $2015 ; 252$

23. Agnivesha, Charaka, Dridabala, Charaka Samhita, Nidana Stana, Unmadanidana, 7/11, edited by Yadavji Trikamji Acharya, Chaukhambha Sanskrit Sansthan, $2015 ; 224$

24. Sushrutha, Sushruta Samhita, NidanaStana, Kushtanidana, 5/6, edited by Yadhavji Trikamaji Acharya, Chaukhambha Sanskrit Sansthan, Varanasi,2017; 283.

25. Agnivesha, Charaka, Dridabala, Charaka Samhita, Nidana Stana, Kushtanidana, 5/4, edited by Yadavji Trikamji Acharya, Chaukhambha Sanskrit Sansthan, $2015 ; 218$

26. Agnivesha, Charaka, Dridabala, Charaka Samhita, Sutra Stana, Kiyantashiraseeya, 17/112, edited by Yadavji Trikamji Acharya, Chaukhambha Sanskrit Sansthan, 2015; 105

27. Agnivesha, Charaka, Dridabala, Charaka Samhita, SutraStana, Tisraishaneeya,11/49, edited by Yadavji Trikamji Acharya, Chaukhambha Sanskrit Sansthan, $2015 ; 77$

\section{Source of Support: Nil \\ Conflict of Interest: None Declared}

How to cite this URL: Arun Kumar M \& Nagaraj S: Elucidating Vyadhijanaktva Of Kushta In Terms Of Sheetoshna Vyatyasa Nidana. International Ayurvedic Medical Journal \{online\} 2021 \{cited March, 2021\} Available from: http://www.iamj.in/posts/images/upload/584 588.pdf 